\title{
Mining Against the State? Gold Mining and Emerging Notions of Territoriality in Southeastern Venezuela
}

\author{
NATALIA GARCIA BONET
}

\section{University of Kent}

\begin{abstract}
The current economic crisis in Venezuela has drawn members of Pemón communities towards the practice of informal (illegal) gold mining, as mining - practised alongside other 'traditional' economic activities - is a more effective source of income than waged jobs. The increased involvement of Pemon people in informal mining has encouraged their partial retreat from the state's frontiers, and it reveals transformations in the ways in which local people imagine and relate to the Venezuelan state. These transformations are embodied in both a reorganisation of the space, and in burgeoning notions of land ownership.
\end{abstract}

Keywords: informal mining, socio-spatial organisation, Amerindian-state relations, Pemón, Venezuela, economic crisis

\footnotetext{
'When the Spanish came to Chirikayen they had to attack the Indians three times before they could take over their gold. On the first attack, the Indians shot arrows at them when they were coming up the mountain, so they had to retreat. The second time, they [the Spanish] waited for all the men to come down and they ambushed them and killed them all, so there were only women and old men left to protect the area. The third time, the old men in the community were prepared for the attack, and as soon as the Spanish started walking up the mountain they shot arrows at them [...]'.
}

The above story, told by a young Pemón woman in a community of Gran Sabana (Great Savannah), in Southeastern Venezuela, is illustrative of the mythologised ways in which local actors construct their history of occupancy over the territory. It sheds light on the role played by gold - a highly contested resource - as the catalyst for both the process of colonisation and 
indigenous resistance. Although the story is set at the beginning of the Spanish conquest, it resonates with Pemón contemporary concerns of encroachment (Angosto, 2017). This perception finds justification in the mass flow of miners to the Gran Sabana area, in its increased militarisation, and lately, in the positioning of gold as an axis of the Venezuelan government's state building agenda.

Imaginaries that connect gold extraction to ideas of territoriality are illustrative of a moment in which the role of the state in Amerindian communities is being recast. The Venezuelan state has historically been experienced by the inhabitants of Gran Sabana first as an expansive territorial state, whose priority was the control over national territory (Foucault, 1991), and then, after the discovery of oil in the early $20^{\text {th }}$ century, as a 'magical state' (Coronil, 1997) with the role of distributing national resources - in the forms of cash transfers and basic goods - among the people. This form of state tutelage was prevalent among the governments of the second part of the $20^{\text {th }}$ century and was exacerbated during the Bolivarian Revolution by high international oil prices at the time. Understandings of the state are thus tied to the fluctuations in international oil prices. When these prices drop and the 'magical' state fails to act as an effective distributor of resources, it is perceived by peripheral populations as an expansive, predatory force, which attempts to dispossess them from their lands, alienating them, in turn, from resources to which they lay historic claims. This perception of encroachment prompts Amerindian groups to become active managers of the lands they occupy, thus fostering new ideas of land ownership.

Most Cariban speaking Pemón peoples live in the area of Venezuela known as Gran Sabana. The region is located in the Guiana shield between the Atlantic Coast, the Amazon, and the Orinoco rivers, in the southeastern end of the Venezuelan territory. The material for this paper emerges from research on Amerindian state relationships through schooling, based on a year of fieldwork (2014 2015), using the methods of participant observation, everyday conversations and unstructured interviews within a small community (of approximatively 120 people) located in the vicinity of Santa Elena de Uairén (the largest town in Gran Sabana).

Discourses about informal gold mining, reproduced in schooling events, by local school authorities, indigenous, and teponkén (non-indigenous) educators, often portray it as destructive and chaotic, and position it directly against traditionally Pemón economic activities, such as swidden agriculture. These portrayals respond to the state's attempt to centralise and manage mineral resources. Moreover, they are closely linked to idealised imaginaries of indigeneity, as well as a 
form of agrarian idealism fostered by the Bolivarian Revolution's discourse, which positions swidden agriculture as the solution to the nation's dependency on foreign imports.

In spite of these negative associations, there are important continuities and complementarities between small-scale mining and other Pemón traditional economic practices. The material presented in this paper, therefore, eludes dichotomous analyses of mining as an activity forced upon people by large-scale multinational corporations (see Ballard and Banks 2003), and resulting in the forceful proletarisation of indigenous peoples and rural peasants (see Nash, 1972; Taussig, 1980). Conversely, the paper draws from critical approaches to political ecology such as those developed by Macmillan (1995) and Lahiri-Dutt (2006; 2012), which explore the complementarity and compatibility between artisanal mining and indigenous forms of production; while simultaneously highlighting how the condemnation of small-scale mining responds to national, regional and global projects of resource governance (Escobar, 1995).

Engagement in illegal gold mining can be framed within Amerindian tendencies towards fragmentation and dispersal, as a common strategy for mediating contact with the nation-state and counteracting its centralising action (Clastres, 1987; Santos Granero, 2002). For the Pemón, gold mining represents a retreat from the state, in both economic and spatial/territorial terms. It implies replacing the state as a distributor of basic goods, and, simultaneously, a spatial relocation away from urban centres towards mines located in sparsely populated areas. Nevertheless, the relationships between indigenous people and the state that crystallise through mining activity cannot be reduced to a simple conflict between indigenous resistance and state expansion.

The terms Artisanal and Small-Scale Mining (ASSM and SSM) refer to informal, (often illegal) mining practiced by individuals or groups in the so-called Global South (Lahiri-Dutt, 2012). The definition of artisanal mining is often contested and depends on different factors, such as the use of minimal machinery and the lack of legal permits (Ibid.) Despite the polemics surrounding the terms ASSM and SSM, in this article the informal mining practiced within the Canaima National park will be referred to as SSM in order to differentiate it from large-scale legal and illegal mining. Small-scale mining in this case is developed both against and in parallel to the project of state extractivism, as it involves sometimes contentious and sometimes cooperative interactions with state actors.

The first section of the paper describes the history of resource extraction and state expansion in Venezuela. This is followed by a brief description of informal mining in indigenous communities 
in connection to people's aspirations for a good life. The next section explores how the sociospatial organisation, prompted by the economic crisis and enabled by informal mining, is linked to the diminished allure of the state. The final section discusses how this re-organisation of space has prompted new notions of land ownership. The paper argues the socio-spatial organisation promoted by gold mining represents not only a way to navigate the current economic crisis, but also a strategy to counteract the centralising action of the state. Paradoxically, this results in adopting definitions of indigenous communities and lands as discreet spaces, consistent with state-instigated reorganisations of the space.

\section{Resource Extraction and State Expansion in Venezuela}

The territory of Gran Sabana, rich in both renewable and mining resources, has been a longstanding goal of state expansion for the Venezuelan nation. The relationship between gold extraction and the conquest of the territory is not only the theme of mythologised retellings of the past like the one presented at the beginning of this paper. In Guyana, 'sueños doradistas' (Dreams of Gold) were one of the main catalysts for the long and arduous efforts, by the Spanish Crown, to control the territory (Perera, 2003). During the time of colonial expansion, this project took the form of aggressive territorial occupation prompted by the abundance of gold; what Miguel Angel Perera (2003) defines as the history of a ransacking. This struggle between colonial powers and local actors over mining resources manifested in different exchanges, from violent warfare to trade and the establishment of strategic alliances with independent agents (mostly adventurers and corsairs) (Whitehead, 1988). The governance of frontier populations and the process of expansion of the great territorial states since colonial times has been, therefore, closely linked to these extractivist agendas.

After the independence of Venezuela from the Spanish crown, the expansion into the south has progressively become part of a project of governmentality (Foucault, 1991). In this project, sovereignty over the population is prioritised over the control of the territory. Similar to other Amazonian contexts, this process of state expansion arrived in consecutive waves, in which the state's different frontiers - the administrative frontier, the extractive frontier, and so on - have expanded and contracted in different rhythms, transforming the history of the territory 'into a fragmented quilt of time frames' (Little, 2001: 1). In other words, the expansion of the extractive frontier has not always been accompanied by the expansion of the state's administrative frontier, 
neither have extractivist projects always been accompanied by a process of registration and active incorporation of peripheral populations into the state.

Territorial expansion continued during Venezuelan Republican history, through the use of missionary penetration - this time aided by the Venezuelan state, and linked to a longing for modernity - with the goal of transforming frontier populations into 'modern' Venezuelan citizens (Angosto, 2013). During the second half of the $20^{\text {th }}$ century, this project was linked to the much larger regional and global process of post-colonial state development after World War II (Escobar, 1995; Coronil, 1997), propelled by the so-called 'Truman doctrine' (1949). The doctrine implied a move towards global development, founded on the desire to eradicate poverty and backwardness from countries in Asia, Africa and Latin America, by replicating the living conditions, education and values of the so called 'advanced' societies in countries situated at the peripheries of the West.

As mentioned above, after the discovery of oil at the beginning of the $20^{\text {th }}$ century, the wax and wane of the state's frontiers has been tied to fluctuations in the international price of oil. This is paralleled by periods of expansion, marked by the political incorporation of marginal populations, followed by periods of state absence, in which these populations are often excluded from prevailing regimes of citizenship defined by the distribution of the nation's resources (Yashar, 2005). High oil prices during the late 1960s and early 1970s allowed the government of then president Rafael Caldera to lead an aggressive project of state expansion - which came to be known as La Conquista del Sur (the conquest of the south). The project included the development of transport and communications infrastructure to connect the south of the country to the coastal cities in the north, to encourage the arrival of settlers into these less populated areas and thus facilitate the state's exploitation of mineral and other natural resources.

During this time, the area of Gran Sabana came to be managed by the Canaima National Park; founded in 1962. In the early 1970s the park formed part of a series of protected areas, Areas Bajo Régimen de Administración Especial (Areas under Special Administration Regime) (ABRAE), which by the 1980s covered approximately 65 percent of the territory of Bolivar state (Bello, 1999). Some of these protected areas were simultaneously recognised as indigenous territories and placed under the jurisdiction of the Ministerio del Medio Ambiente y Recursos Naturales Renovables (The ministry of the environment and renewable resources). The aggressive initiative of state expansion embodied in La Conquista del Sur had the goal of modernising and assimilating the 'backward' and isolated southern territories through spatial re-organisation, and this required, among other things, establishing clearly defined territories, like the national park, 
where natural resource exploitation was controlled by state organisms. The conflation between the national park and indigenous territories symbolically positioned indigenous people as the only ones with the right to exploit these resources. This process of spatial organisation is ongoing, as $L a$ Conquista del Sur represents but one episode in the project of state expansion into the southern territories of the country.

The 1980s and 1990s were a time of political and economic instability in Venezuela. An economic crisis prompted by low oil prices drove the national government to seek the aid of the International Monetary Fund (IMF), and to consequently adopt a series of neoliberal policies in order to meet IMF lending conditions. This resulted in the social revolt of 1989, better known in Venezuela as 'el caracazo', and the failed military coup of 1992, led by Hugo Chávez, which was crucial for his election to the presidency in 1998. Chávez rose to power with the largest electoral margin in forty years, and his popularity was partly sustained by the claim that there existed a mismatch between previous forms of government and the Venezuelan people, which needed to be mended through a radical political reform (Lee Van Cott, 2003). One of the pillars of this radical reform was the recognition of previously neglected minorities, such as indigenous peoples. For example, the 1999 Constitution of the Bolivarian Republic of Venezuela (CRBV), was the first to provide indigenous peoples with a host of rights (Ibid.; Angosto, 2015;), including 'native rights over the land, which they have ancestrally occupied' (CRBV, 1999: Article 119). As such, the spatial re-organisation started during the 1970s became explicitly linked to the collective ownership of the land.

Aided by extraordinarily high oil prices during the early 2000s, Hugo Chavez led one of the most successful projects of state expansion in Venezuelan modern history. This project was embodied in the proliferation of state funded schools, primary care centres and a series of nationwide governmental programmes, misiones (missions), which facilitated people's access to schooling, their participation in the pensioner system, among other things. The early 2000s, then, were characterised by an increase in the influx of resources from the state to the people, reaching areas of the territory that had been neglected by La Conquista del Sur. During this time, the Bolivarian government positioned itself as the main distributor of goods to indigenous communities, in the form of foods, household and school supplies and even gasoline. This aid was often administered, requested and redistributed by the community schools, institutions that represent a microcosm of the state within indigenous communities, and that, thus, reproduce the centralising action of the state (Rival, 1996). 
Unlike previous waves of state expansion, aimed at transforming frontier populations into modern citizens, the Bolivarian process was informed by global and regional transformations in identity politics, such as the global multicultural turn and the regional project of interculturalism. In this sense, it advocated for progressive incorporation of Amerindian groups into the nation while simultaneously preventing their acculturation (cultural loss). Enfranchising previously neglected populations served the Revolution's claim of a radical political reform. At the same time, it strengthened indigenous peoples' inclusion into regimes of citizenship, defined by the redistribution of state resources, stemming from la renta petrolera (the oil rent). The distribution of the oil rent, then - defined as an extraordinary benefit, over the total costs of oil production delineates who belongs to the Venezuelan nation and who does not.

The research for this paper took place in the aftermath of this period of massive incorporation (between 2014 and 2015). During this time, the steadily decreasing international oil prices, along with the country's long-standing dependency on oil revenue, resulted in new waves of informal workers migrating to the mining sites in the north of Bolivar state with the hope of finding work. This migration, however, has not been accompanied by infrastructural development. On the contrary, it coincides with, and is a response to, a period marked by a contraction of the state's administrative frontier, and by the increasingly intermittent flow of goods from the state towards the peripheries. Amerindian populations, then, are gradually becoming excluded from those regimes of citizenship to which they had only very recently been incorporated, and they have developed a series of strategies to deal with this disincorporation; engagement in small-scale illegal mining is one of them.

\section{Mining and Aspirations for the Future}

As mentioned above, gold mining in the Canaima National park is predominantly an illegal activity, as it is practiced without official, state-granted concessions (Rubio, 2011). The connotations of illegality cast upon all forms of mining independent from the Venezuelan state emerges from mining laws dating back to the colonial era, which stipulate that all subsoil resources belong to the nation and, as their administrator, the state has the exclusive prerogative to their exploitation. This long-standing constitutional tradition was reinforced by legal frameworks developed early in the twentieth century after the discovery of oil (Coronil, 1997). In 2001, the new regulations of the Mining Law (Reglamento General de la Ley de Minas), in line with legal frameworks set-forward by the 1999 Constitution of the Bolivarian Republic of Venezuela (CRVB), included the granting 
of concessions for artisanal, small-scale mining (ASSM) to individuals and cooperatives (Title III, Art. 38 -64). However, mining concessions require an extensive production of bureaucratic documents and the registration of all mining activity for fiscal purposes, which makes it an unattractive choice for many small-scale miners in Gran Sabana. Despite the government's socialist, anti-imperialist platform, this new mining law contrasts with other economic policies, which - in line with other Latin America contexts - seek to attract foreign direct investment. This is evidenced in a large-scale mining project in the North of Bolivar state, known as Proyecto Arco Minero del Orinoco (Orinoco's mining arc project), set up to combat the current economic crisis.

Amerindian people's engagement with gold mining can hardly be considered a recent phenomenon. Cleary (1990) presents historical records of indigenous groups in the Brazilian Amazon using gold for both trading and decorative purposes as early as the seventeenth century. Similarly, Macmillan (1995) states that mining is intrinsic to the Amazonian region and that smallscale informal-sector mining has been practiced throughout the region since the eighteenth century, with records of Macuxi (a Pemón group from Brazil) participating in diamond and gold mining since the early 1900s. Most of the contemporary mining done by Pemón people in the proximity of settlements is practised without permits, seasonally, as a complement to swidden agriculture (Rubio, 2011). In the community where this research was conducted, people would go to the mines for one or two weeks at a time, then return to the community and their daily productive activities like fishing, working in the family сописо (swidden garden) or, in the case of children, attending school.

Due to the lack of permits, mining activity is generally concealed from outsiders. However, one does not need to spend much time in a community to see signs of it everywhere: bateas de oro (gold sieves) used for panning, and exploratory pits cut deep into the ground, for example. Military presence in the region complicates the free circulation of gold nuggets throughout the area, however, there are ways of circumventing this control, for example, in 2011, a group of Pemon capitanes (local civil authorities) from the southern end of Gran Sabana - an administrative area known as Sector Seis - were able to overcome these controls by striking an informal deal with the military. The deal would allow only Pemón to work in the nearby mines, as long as the mining remained artisanal (excluding the use of mercury or heavy machinery), with a low environmental impact. Although the author cannot attest to its veracity, claiming that their mining is artisanal has been pivotal for indigenous miners to discursively position themselves against other forms of illegal mining considered devastating for the environment. This claim is, however, heavily contested, and 
accusations of the use of mercury and heavy machinery are common and often the cause of intercommunity conflict. Moreover, the uncertainty of this claim has been strategically used by military officials to profit from local mining and has often resulted in open confrontations between community members and military officials.

Those community members who are most accustomed to dealing with outsiders, such as school teachers and community capitanes, are generally wary of openly discussing the mines in front of strangers. Nevertheless, the expectations surrounding mining activity are an everyday topic of conversation among family and acquaintances. This is partly due to the deal negotiated with the military, which allows individuals to work in the mines near their communities without fear of repercussion. Even those who have never visited the mine often refer to mining as a future solution for their current economic struggles. For example, the school teachers - who often talked disapprovingly about other community members' trips to the mines (especially when children of school-age were involved) - would themselves joke about working in the mines in the near future to 'finally' have decent earnings.

The teachers' ambivalence towards mining can be read as the product of their interstitial position within the community, as representatives of the school (and thus the state) in front of the community, and simultaneously, the community in front of the state (see Amodio, 1989; Rival, 1996:154). Nevertheless, the fact that even those community members who are directly employed by the state see in mining a solution to their current economic struggles is illustrative of its pervasiveness as an aspiration for a better future. Even though teachers - as state employees historically enjoyed relative financial security in comparison to other community members, in recent years, there has been considerable migration of local indigenous and non-indigenous teachers towards the mines, leaving the classrooms empty (see Morillo, 2015). In this sense, most community members have engaged in mining at one point or another, or are planning to do so in the future. Although adult men are those most commonly absent from the community, women, elders, and sometimes even older children, would often accompany the men to help with either complementary chores like cooking, or actively engage in mining themselves.

Neither the mine nor the community are clearly defined spaces. Many Pemón communities are organised by a dispersed settlement pattern of households with great distances between them (Thomas, 1982; Rivière, 1984), and mining sites can sometimes be located in the proximity of previously established family settlements. In other instances, family groups relocate during periods of the year to mining sites, establishing temporary settlements that might be farther away from their 
regular place of residency and from settlements inhabited by other community members. Whilst this continuous movement implies a continuity in Pemón fluid perceptions of the space, the close distance between some mines and family settlements has often resulted in relationships of partial ownership over the land by patamunás (heads of households). Although instances of land enclosure are unlikely, patamunás and community capitanes determine 'outsiders' access to the mines. As will be explained below, this control over land access highlights burgeoning conceptions of land and territories as discreet spaces with progressively clearer limits. These discreet spaces can coincide, in more scattered communities, with the territory of family settlements, or with the community as a whole in more centralised ones.

\section{Retreating from the State}

As mentioned above, the economic crisis in Venezuela has encouraged large numbers of settlers from different parts of the country to relocate close to the many mining sites in Bolivar state. As Gran Sabana is officially indigenous territory and a protected area, establishing settlements in the National Park is forbidden to non-members of indigenous communities. The areas surrounding the National Park, however, are increasingly occupied by non-indigenous who expect to find in the mines the answer to their dire economic situation caused by the nation-wide economic crisis. This is evidenced in the proliferation of improvised housing and shanti towns in in the vicinities of Santa Elena de Uiaren, which in 2014-2015 was an ongoing source of concern among neighbours, instigating the gathering of impromptu cabildos (town meetings) to discuss the occupations. This internal migration places increased pressure on already highly contested territory, as well as contributing to the feeling of encroachment on indigenous communities.

Similarly, indigenous peoples' responses to the economic crisis and to the state's inability to act as an effective redistributor of resources have been marked by a retreat from waged labour, which is no longer viewed as profitable. They have also resulted in the abandonment of temporary urban dwellings that - as in other Amerindian contexts - were used as intermittent residencies by community members who had taken jobs in the city (Alexiades and Peluso, 2015). In light of the scarcity of basic goods and the devaluation of wages, this 'return' to their natal communities has been prompted by the advantages of combining swidden agriculture as a reliable source of food, and mining as a source of sporadic income. This return can also be read as a reaction to the 
encroachment by outside settlers; many people referenced increasing insecurity as a reason for moving back to their communities.

The practice of informal mining as a response to the economic crisis has resulted in a reversal of processes of indigenous urbanisation and incorporation to the waged-labour economy, with the cyclical, back and forth circulation between urban and rural contexts being partially replaced by cyclical movements between the community and the mine. This is the case for many young adults from the community where this research was conducted, who graduated from school at the end of the 1990s and went on to take waged jobs and establish semi-permanent residences in Santa Elena de Uairén. Now, most of them have abandoned their urban dwellings, disappointed by the opportunities that the city has to offer. Even though they still travel regularly to town to trade, their residency is now shared between the community and the mines.

One example is Alma (all names have been anonymised), a single mother in her early 30s, who had gone to finish High School in Santa Elena after completing primary school in her community. She held various different jobs in town, working in a restaurant and a few shops. However, in the years prior to 2014, she could only find work cleaning houses and taking care of other people's children. As a result, she decided to move back to live in the community to work in the conисо and the mine: 'I've had it! Every day is the same, I keep doing the same job, and for what? Every day things get more expensive and I can't do anything with the money I make', she commented in regard to her decision. The transformation in Alma's livelihood aspirations demonstrate her disappointment with formal employment as means to provide a 'good life'; wagedlabour is seen as futile, in light of the extreme inflation of Venezuela's currency.

Alma's aspirations are also based on the experiences of other community members of her generation, like Adriana and Eduardo, a couple in their early 30s who spend six months of the year in the mine and the other six working in their family conисо. The couple has grown an impressive conuco on the banks of the Kukenan river, of such range and beauty that it is admired by many community members. Single mothers close to Adriana's age would visit the conисо and be sent home with bags full of different vegetables (sweet manioc, bitter manioc, peppers, sweet potatoes and so on). The young couple attributed their prosperity to their retreat from the city and the school, and specifically to their involvement in mining. Adriana was one of the first members of her generation to return to the community after holding different waged jobs in Santa Elena. By abandoning her waged-job and urban dwellings, she was also one of the few younger women in the community who could dedicate lengthy hours to working in her family's conuco, a desired activity 
made possible only by her involvement in mining. During the earlier wave of incorporation of young community members to the waged-labour economy, most swidden gardens in the community were left in the hands of community elders, with young adults only working on them sporadically upon visits to the community when they collaborated in larger tasks such as the harvesting of manioc.

Informal mining has not only become an alternative to wage labour, but it is also substituting governmental programmes as a way to access commodities. Most significantly, this has resulted in a de-centralisation of the school in indigenous communities, a decrease in the attraction of the school/state as a space in which children prepare for the wage labour economy, and from where most community applications for governmental programmes are completed. Because of this, at local schooling events, illegal mining is portrayed by school district authorities and local teachers as a destructive activity, allegedly linked to the abandonment of the household and to school dropout. In these events, mining is not only positioned against schooling and official forms of labour, but also against other, 'traditional' productive activities, such as swidden agriculture, thus concealing the complementarities and continuities between the two. Moreover, official discourses about the damaging effects of SSM, reproduced by the school, highlight the internal contradictions of a burgeoning discourse that positions large scale mining as one of the axes of the Revolutionary Government's nation building agenda, whilst, simultaneously, condemning the mining practised by indigenous peoples..

Discourses that condemn SSM practiced by indigenous people in Gran Sabana often liken these mines to the large-scale illegal mines run by sindicatos in the north of Bolivar state. Although generally translated as 'unions', in the context of illegal mining, sindicatos refers to mafia warlords who control the mines. The term, which is widely used in the area, reflects established parallels between mining sindicatos and workers unions, as both regulate access to the mines and the distribution of resources within them. Similar to other SSM contexts around the world (see Martinez-Castilla, 1990; Lahiri-Dutt, 2006), mines in indigenous communities are often discussed in the media as being smaller versions of these large-scale counterparts. This comparison overlooks the fact that many of the mines located near indigenous communities are directly administered by patamunás (heads of households) and local capitanes. In fact, according to many research interlocutors, the mines in Gran Sabana have not been appropriated by sindicatos precisely due to the constant vigilance of local indigenous actors. 
Despite enabling a retreat from urban centres and from state institutions like the school, extractive activities do not entail a complete retreat 'inwards', as they simultaneously intensify contact with 'outsiders' and the market economy - mainly by increasing people's capacity for consumption and by positioning actors in networks of trade that cross international frontiers. The current economic crisis has resulted in diminished dependency on commodities offered by the state, and mining has thus become one of the main settings in which indigenous people negotiate with the world of teponkén (non-indigenous peoples). This scenario challenges Macmillan's (1995) argument that social relationships in the mining economy of Amazonia are essentially noncapitalist. The reality of mining in Gran Sabana seems more complex, as it blurs the clear-cut separation between indigenous and capitalist modes of production, especially the idea that the transition from one to the other represents an irreversible process (see Taussig, 1980 and Godoy, 1990 for a critique). More than a complete retreat from the state's frontiers, the practice of informal mining encompasses a reconfiguration in the interactions between members of indigenous communities, the market economy, and the state.

While mining activities promote encounters with non-indigenous peoples, they also create the need to keep those 'outsiders' at bay in order to avoid state surveillance, and to exercise control over mining resources within indigenous territories. Therefore, the abundance of gold near indigenous communities has provided a catalyst for re-drawing the spatial limits of communities and family settlements, prescribing the rights of outsiders (including state institutions) to occupy and utilise those lands, as described in the following section.

\section{Bounded Communities and Family Settlements}

The spatial re-location prompted by informal mining implies two different, somewhat contradictory phenomena. On the one hand, it represents a process of reversal to the spatial centralisation of the community imposed by the colonial process and then by the Republican state. On the other, the necessity to regulate access to the mines, and to the resources extracted, reproduces ideas of land ownership and of territories as limited spaces, which both contradict Pemón fluid uses of the land and remain consistent with the state's re-organisation of the space into discreet units (Chirif and García Hierro, 2007). These burgeoning understandings of land as bounded areas take different forms depending on the level of centralisation of communities, as illustrated below.

In June 2015, the heavy rains at the beginning of the season stirred up a gold bulla in the community of San Antonio de Morichal. Literally translated as 'commotion' or 'scandal' in the 
context of mining, the word bulla is used metaphorically to refer to the excitement and agitation surrounding the discovery of large amounts of gold after superficially stirring the dirt. During the first three days, rumours about the bulla pulled people from different communities across Gran Sabana towards San Antonio. It also encouraged fears and hearsay about the imminent arrival of mining sindicatos (mafia warlords). In light of the threatened influx by outsiders, the capitán of San Antonio decided to close the community's entrance to non-members and deny the presence of a bulla, hanging a banner by the entry that read 'closed by the decision of the community'.

For the capitán of San Antonio, closing the community to 'outsiders' was relatively easy, as most houses are organised around the school building, and the community has somewhat defined geographical boundaries. Nevertheless, defining the limits of scattered communities, in which settlements are at greater distance from each other, is more complicated. These communities can only be said to exist through the intensity of inter-settlement visits, trade and cooperation that allows a mapping of connections between different households (Thomas, 1982; Riviere, 1984). In these communities, the territorial limits of family settlements are blurry. Although most people recognise others' rights over the land surrounding their family's houses and conucos; rivers, ponds and patches of forest in the broader proximity of settlements are often treated as common resources, used for fishing, hunting or mining. Moreover, the slash-and-burn nature of conucos implies that these are not occupied for periods longer than three years.

Although capitanes make decisions at the community level, they hold little authority over the land surrounding individual family houses (Thomas, 1982). Therefore, in disaggregated communities, land access is regulated by individual heads of households. Two or more families who engage in collaborative work for productive activities like dropping barbasco (a poisonous root used for fishing) or harvesting manioc, are likely to share the profits of the mining near their settlements. However, when the mining is carried out by outsiders (usually teponkén), patamunás are in charge of negotiating access to the land near their settlements, leasing it out for gold exploration in exchange for payment. In these instances, profits would not be shared with other families. Making profits from land located in the proximity of other households or swidden gardens, without previously negotiating access, can generate conflicts between different households.

The ways in which people lay claims to extensions of land are manifold. In ordinary interactions, most people recognise the rights of the families who are using or living on the land (Butt Colson, 2009). In these cases, having built a house or a swidden garden in a piece of land is usually an effective way of laying claims over it. Nevertheless, certain forms of land occupancy like cattle ranching, which often require land enclosure, can cause serious conflict among family groups 
who occupy adjacent territories. Therefore, even though the use or occupancy of land is not usually a cause for conflict, the demarcation of lands as bounded spaces is, because while the former implies preferential rights over the resources near a family settlement, the latter entails a form of land 'ownership'.

The concept of 'owning' land is alien to Pemón vernacular. However, it has entered peoples' imaginaries since the (mainly unfulfilled) promises of collective titling for indigenous people sanctioned in the 1999 constitution (Sletto, 2009). Claims to collective lands are articulated within the Bolivarian revolution's construction of 'official' indigeneity as a symbol of resistance against invasions by foreign powers (Garcia Bonet, 2018). For example, in the community where this research was conducted, settlement areas were renamed, replacing their Spanish names with names included in stories of Makunaima, the supreme culture hero of Pemón mythology (Armellada, 1964; Rodríguez, 2006), who gave shape to the mountains and rivers in the Kukenan Valley (southern Gran Sabana). This renaming implies both a form of resistance to colonialism and a claim to first occupancy over the territory, as it links Pemón presence and usage of the land to immemorial times before recorded history.

Rights over the land are therefore not only associated with occupation in the present, but also to local reconstructions of the past and to mythological time. In scattered communities, households relocate multiple times to different settlements throughout the years, often motivated by the proximity to natural resources (fertile soils in river banks and forest edges, as well as mining resources). The settlements are not selected at random; people tend to return to their old settlements and re-cultivate old swidden fields, mapping cycles that often span beyond the lifetime of specific family members (Thomas, 1982:45; Rival, 2002). Family connections also shape the movements associated with mining, as people often refer to their mining excursions as 'going to visit family and friends'. These trips to the mines are indistinguishable from family visits, both in terms of length and impact on people's daily lives. In fact, as in other Amazonian contexts, these two activities tend to overlap (see MacMillan, 1995: 120). Talking about 'family visits', therefore, does not only represent a veiled way of discussing mining excursions, but a way of highlighting that the mining is taking place in lands that belong to a family with whom one maintains relationships of conviviality and cooperation.

Crucially, the distinction between centralised and scattered communities usually depends on the length of contact with state institutions. State penetration has produced a process of sociospatial reorganisation (Rubenstein, 2001), marked by centralisation, and the concentration of family settlements around government buildings such as the school or the mission (Rivière, 1984; Rival, 
1996; Rubestein, 2001; Killick, 2008; Walker, 2015). Nevertheless, between 2014 and 2015, this process of centralisation started to revert, with families spatially dispersing away from community centres and losing interest in state institutions like the school. In some centralised communities, elders, who feel disillusioned by what the state has to give, have abandoned their houses near the mission centres to relocate to faraway places that had been unoccupied for years. In these cases, 'living apart' (Killick, 2005) is not only the result of Amerindian tendencies towards dispersal, or of the decrease in the attraction of the state, but also provides an alternative means of livelihood to navigate the economic crisis. Long distances between settlements, and from state buildings, allows people to pursue mining activities with little to no surveillance from state institutions, while simultaneously avoiding inter-community conflicts over mining resources. In light of this tendency towards dispersal, it can be expected that claims to land ownership will be progressively laid out in relation to individual family settlements rather than to centralised communities. The socio-spatial organisation prompted by mining, thus, implies a movement of dispersal; away from government buildings and state surveillance, and, simultaneously, a burgeoning understanding of lands occupied by families as discreet spaces, which can be owned by family groups.

\section{Conclusions}

The economic and political crises in Venezuela have greatly intensified since 2015 and informal gold mining is increasingly perceived as an option for individuals seeking viable livelihoods. This phenomenon is evidenced in the increasing migration of people from coastal cities in the north of the country to the informal mines located in the south, which is beginning to revert the massive move towards the cities in the north prompted by the discovery of oil at the beginnings of the twentieth century. This reversal is not only in terms of the direction of movement, but also in terms of the role played by the state in overseeing extractive activities and implementing infrastructural development. Informal gold mining thus represents a movement against state-sanctioned economic activities. The increased involvement of indigenous and non-indigenous actors in mining is a direct result of the disenchantment with the state and of its failure to act as an effective provider of stable employment or goods.

Even though engagement in informal mining is in line with Amerindian tendencies towards dispersion and atomistic forms of organisation, it has also increasingly encouraged ideas of land ownership. These are rooted in an understanding of territories as bounded, limited spaces, which 
have been imposed on Amerindian peoples since colonisation. Ideas of land ownership coupled with the tendency towards fragmentation implies that land ownership is progressively claimed by families or individuals, signalling to burgeoning understandings of land as private property. The spatial organisation prompted by the economic crisis and enabled by informal mining is, thus, somewhat paradoxical, as it represents a form of 'keeping the state at bay' while simultaneously using forms of social-spatial organisation fostered by the state.

New territorial boundaries resulting from this process of spatial re-organisation are redrawing the limits between Amerindian peoples and the state. This redrawing, however, cannot be understood in terms of a simple opposition between state expansion and indigenous resistance, but as an example of the multifaceted ways in which people engage with the ongoing processes of state expansion and contraction. In these, the state is sometimes perceived as a benevolent, inclusive distributor of the nation's resources, and sometimes as a predatory force, competing with indigenous people over land and resources. Even though this moment of state contraction is just beginning, as the crisis in Venezuela deepens and the power of the state diminishes, atomistic notions of land ownership might strengthen, creating forms of socio-spatial organisation that resist the state whilst simultaneously reproducing state structures..

\section{References}

Alexiades, M. and Peluso, D. (2015) 'Introduction: Indigenous Urbanization in Lowland South America'. Journal of Latin American and Caribbean Anthropology 20(1): 1-12.

Amodio, E. (1989) 'Introducción: escuelas como espadas' in E. Amodio (ed.) Educación, Escuelas y Culturas Indígenas de América Latina, Tomo I. ABYA-YALA: Quito, 5-23.

Angosto, L. (2017) 'Indigenous Peoples, Social Movements, and the Legacy of Hugo Chavez's Governments'. Latin American Perspectives 44(1): 180 - 198.

Angosto, L. (2015) Venezuela Reframed: Bolivarianism, Indigenous People and Socialisms of the Twenty First Century. Zed Books: London.

Angosto, L. (2013) 'Mundo perdido, paraíso encontrado: Lugar, identidad y producción en la Gran Sabana, Venezuela'. Revista Colombiana de Antropología 49(1): 11-43. 
Armellada, C. (1964) Taurón pantón. Cuentos y leyendas de los indios Pemón-Gran Sabana, Estado Bolívar, Venezuela. Ministerio de Educación, Dirección de Cultura y Bellas Artes: Caracas.

Ballard, C. and Banks, G. (2003) 'Resource Wars: The Anthropology of Mining', Annual Review of Anthropology 32: 287-313.

Bello, L. (1999) Los derechos de los pueblos Indígenas en Venezuela. IWGIA: Copenhague.

Butt Colson, A. (2009) Land: The Case of the Akawaio and Arekuna of the Upper Mazaruni District, Guyana. Last Refuge: Panborough.

Clastres, P. (1987) Society Against the State: Essays in Political Anthropology. Zone Books: New York.

Cleary, D. (1990) Anatomy of the Amazon Gold Rush. Macmillan in association with St. Antony's College, Oxford: Basingstoke.

Coronil, F. (1997) The Magical State: Nature, Money, and Modernity in Venezuela. University of Chicago Press: London.

Escobar, A. (1995) Encountering Development. Princeton University Press: Princeton.

Foucault, M. (1991) 'Governmentality’ in G. Burchell, C. Gordon and P. Miller (eds.) The Foucault Effect, Studies in Governmentality, The University of Chicago Press: Chicago, 87-105.

Garcia Bonet, N. (2018) To the School and Back: Intercultural Education, Identity Construction and Pemón-state Relationships in Southeastern Venezuela, $\mathrm{PhD}$ edn, University of Kent: Canterbury.

Godoy, R. (1990) Mining and Agriculture in Highland Bolivia: Ecology, History, and Commerce Among the Jukumanis. Arizona University Press: Tucson.

Killick, E. (2008) 'Creating Community: Land Titling, Education, and Settlement Formation among the Ashéninka of Peruvian Amazonia', Journal of Latin American and Caribbean Anthropology 13(1): 22-47.

Lahiri-Dutt, K. (2006) 'May God Give us Chaos, so that we can Plunder: A Critique of Resource Curse and Conflict Theories'. Development 49(3): 14-21. 
Lahiri-Dutt, K. (2012) 'Digging Women: Towards a New Agenda for Feminist Critiques of Mining'. Gender, Place and Culture 19(2): 193-212.

Lee Van Cot, D. (2003) 'Andean Indigenous Movements and Constitutional Transformation: Venezuela in Comparative Perspective'. Latin American Perspectives 30(1): 49-69.

Little, P.E. (2001) Amazonia: Territorial Struggles on Perennial Frontiers. Johns Hopkins University Press: Baltimore.

MacMillan, G. (1995) At the End of the Rainbow? Gold, Land and People in the Brazilian Amazon. Earthscan Publications: London.

Martinez-Castilla, Z. (1990) 'Child Labour in Traditional Mining: Molehuaca, Peru' in N. Jennings (ed.) Child Labour in Small Scale Mining: Examples from Niger, Peru and Philippines. ILO: Geneva.

Morillo M. (2015) Aulas sin maestros. [WWW document] http://lascronicasdelafrontera.blogspot.com/2015/12/aulas-sin-maestros.html. [Accessed 6, August, 2018]

Nash, J. (1972) 'The Devil in Bolivia's Nationalized Tin Mines'. Science and Society 36(2): 221233.

Nuñez, J.P. (2016) Extractivismo en Venezuela: Las venas siguen abiertas. PROVEA: Caracas.

Perera, M. (2003) La Provincia Fantasma. Guyana, siglo XVII. ecología cultural y antropología histórica de una rapiña 1598-1704. Universidad Central de Venezuela (UCV): Caracas.

Rival, L. (2002) Trekking through History: The Huaorani of Amazonian Ecuador. Columbia University Press: New York.

Rival, L. (1996) 'Formal Schooling and the Production of Modern Citizens in the Ecuadorian Amazon' in B. Levinson, D. Foley andand D. Holland (eds.) The Cultural Production of the Educated Person. State University of New York Press: New York.

Rivière, P. (1984) Individual and Society in Guiana: A comparative Study of Amerindian Social Organization. Cambridge University Press: Cambridge. 
Rubenstein, S. (2001) 'Colonialism, the Shuar Federation, and the Ecuadorian State'. Environment and Planning D: Society and Space 19: 263-293.

Rubio, J. (2011) 'Participación política y cambios culturales en el pueblo Yanomami' in L. Bello (ed.). El Estado ante la sociedad multiétnica y pluricultural: Políticas públicas y derechos de los pueblos indígenas en Venezuela (1999-2010). IWGIA: Caracas, 218-228.

Sletto, B. (2009) “"We Drew What we Imagined”: Participatory Mapping, Performance, and the Arts of Landscape Making'. Current Anthropology 50(4): 443-476.

Santos Granero, F. (2002) 'The Arawakan Matrix: Ethos, Language and History in Native South America' in F. Santos Granero and J.D. Hill (eds.) Comparative Arawakan Histories: Rethinking Language Family and Culture Area in Amazonia. University of Illinois Press: Chicago, 25-50.

Taussig, T. (1980) The Devil and Commodity Fetishism in South America. The University of California Press: Cape Hill.

Thomas, D. J. (1982) Order without Government: The Society of the Pemon Indians of Venezuela. Urbana: London.

Walker, H. (2015) 'Justice and the Dark Arts: Law and Shamanism in Amazonia'. American Anthropologist 117(1): 47-58.

Whitehead, N. (1988) Lords of the Tiger Spirit. A History of the Caribs in Colonial Venezuela and Guyana, 1498-1820, Foris Publications: Dordrecht.

Yashar, D. J. (2005) Contesting Citizenship in Latin America: The Rise of Indigenous Movements and the Postliberal Challenge. Cambridge University Press: New York. 